\title{
Prioritizing Academic Programs and Services: Reallocating Resources to Achieve Strategic Balance
} (Revised and Updated)

Robert C. Dickeson

(San Francisco, CA: Jossey-Bass, 2010, 229 pages)

In 2010, Robert Dickeson updated his 1999 book Prioritizing Academic Programs and Services: Reallocating Resources to Achieve Strategic Balance. In the 2010 edition's preface, Dickeson states he revised the book because he wanted to share what he learned from implementing his seven postulates and because of the heightened stakeholder expectations and fiscal constraints. "In short, the second edition provides a proven approach to reallocating resources in tough times" (p. ix).

Dickeson's second edition is divisible into three sections. Section 1 (chapters 1 and 2), outlines managerial roles and responsibilities. On page 15, Dickeson outlines his seven postulates of academic programs. Beginning on page 30, he explains how institutions of higher learning are organized. Dickeson's comparison of the role of the provost to that of a corporate chief operating office highlights the power and influence of this position.

The second part spans chapters 3 to 9. Here Dickeson outlines his seven postulates and takes the reader on a step-by-step journey that debunks the many dimensions of antiquated academic program prioritization. On close examination, when the academic lingo is removed from these chapters, the information resembles material found in the planning, organizing, control, and strategy chapters of a good organizational behaviour textbook. If your time is limited, spend it reading the first two chapters. Then go directly to the resources at the back of the book.

Journal of Professional, Continuing, and Online Education, Vol 3.1, 2018 Journal de la formation professionnelle, permanente, et en ligne, Vol 3.1, 2018 
Section 3 contains 21 pages of quick-and-dirty, easy-to-read resources. Academic leaders seeking ready-mix solutions to budgets and priority issues should go directly to the resources. While this book may not be a good read, it does place in one volume a blueprint of how academic administrators could approach their roles and responsibilities.

The reality is that since Dickeson published his second edition the higher educational environment has experienced seismic eruptions. The provincial clear-cutting of educational budgets in Canada, the election of President Donald Trump in the United States, the introduction of so-called free secondary education, and the targeted marketing to international students by Canadian and American universities are responses to the topsy-turvy economic cycles that have played havoc with university and college balance sheets. These pressures have forced university presidents to face the threat to the public good of education as a commodity.

Today postsecondary administrators are pressured to declare exactly what is the return on investment for the students participating in higher education programs and just how to go about stabilizing organizational revenues in times of tough economics and changing policies.

On this point Dickeson is bang on, "in the most fundamental form, the basic public policy question is reduced to: What are we getting for our money? This question is made more poignant when one assesses the nation's future in an increasingly global economy where success is measured in available brainpower as well as financial capital" (p. 13).

Dickeson's thesis that institutional changes must be consistent with the organization's mission and values rings true. Adapting differentiation strategies, chasing international students, and combining or dropping courses must align with the organization's deep-seated cultural values. When that alignment is missing, people stick with old and complacent ways of thinking, acting and doing. Under these conditions, organizations stagnate further. And, although policy makers may have no vested interest in whether liberal arts courses are cut in favour of STEM (science, technology, and engineering, mathematics) courses, administrators must have access to an unbiased and systematic process to begin discussions on prioritizing what courses are next to be divorced from university curriculums.

I have no regrets for the time invested in reviewing Dickeson's revised book, Prioritizing Academic Programs and Services: Reallocating Resources to Achieve Strategic Balance. Would I purchase it? No. Would I pick it up and leaf through the pages? Most certainly. Will I take its concepts and introduce them into my lectures? Yes.

If you happen to come by a copy of Dickeson's book Prioritizing Academic Programs and Services: Reallocating Resources to Achieve Strategic Balance don't pass up the opportunity to read it and pass it on.

\section{Review by}

\section{Caterina L. Valentino, PhD, MBA, FACHE, Ryerson University and Athabasca University}

